Plant Tissue Cult. \& Biotech. 20(1): 55-61, 2010 (June)

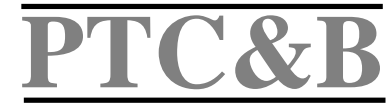

\title{
The Role of Drought Stress on Anther Culture of Wheat (Triticum aestivum L.)
}

\author{
S. M. Shahinul Islam \\ Institute of Biological Sciences, University of Rajshahi, Rajshahi-6205, Bangladesh \\ Key words: Anther culture, Drought stress, Haploids, Triticum aestivum
}

\begin{abstract}
Drought stress was found to pose a significant effect on anther culture of wheat, namely Barkat, Kanchan and Pavon-76. Regeneration potentials of these varieties were determined by estimating the percentage of anther response, embryo induction, embryo regeneration and production of green and albino plants. It was observed that out of five treatments such as $\mathrm{T}_{1}(1 \mathrm{hr}), \mathrm{T}_{2}(3 \mathrm{hr}), \mathrm{T}_{3}(5 \mathrm{hr}), \mathrm{T}_{4}(7$ $\mathrm{hr})$ and $\mathrm{T}_{5}(9 \mathrm{hr})$ only $\mathrm{T}_{2}$ showed highest percentage of embryo yield and green plantlets. The $T_{1}$ and $T_{3}$ also gave significantly better results compared to the control. All the genotypes produced embryos and green plantlets and of them Barkat showed best performance followed by Kanchan and Pavon 76. Genotypes, under this study, produced green plants in addition to albinos but $\mathrm{T}_{4}$ and $\mathrm{T}_{5}$ showed three - fourfold higher albino plant production in comparison to treatments.
\end{abstract}

\section{Introduction}

Since the development of modern plant breeding techniques during the last few decades, rapid progress has been carried out in haploid production by means of in vitro anther culture (Bajaj 1990). The success on wheat anther culture was first reported by the Chinese (Chu et al. 1973, Ouyang et al. 1973) and French (Picard and De Buyser 1973) scientists. The main advantage of using doubled haploids is to attain the rapid homozygosity of the descendants, resulting in a time saving development of new varieties. Homozygous lines were established through spontaneous chromosome doubling during early stages of in vitro culture or through colchicine-induced chromosome doubling of haploids (Zaki and Dickinson 1995).

In recent years, androgenic haploids have been produced in more than 50 genera, but major effort has been made to economically important plants such as cereals and vegetable crops (Cistué et al. 2006, Cao et al. 1995). Haploids have been found to occur in nature also and to be induced by some natural stress conditions. Touraev et al. (1996b) reported that during the plant life cycle stress in general seems to be common trigger for phase change. The stimulatory effect

<shahin_ibsc@yahoo.com>. 
of thermal shocks for anther culture has been successfully adopted to Datura (Nitsch and Norreel 1973), tomato (Debergh and Nitsch 1973) and tobacco (Bajaj and Reinert 1975) to enhance androgenesis. Shen and Veilleux (1995) reported in potato a treatment combining a high temperature shock $\left(35^{\circ} \mathrm{C}\right.$ for $\left.12 \mathrm{~h}\right)$ elevated 11 times higher embryo production in comparison to control. Touraev et al. (1996a) reported that a high frequency of embryogenic microspores from nine Austrian winter wheat genotypes under starvation and heat shock condition. The aim of this study was to determine if the androgenic response could be improved by using drought stress pretreatments in wheat.

\section{Materials and Methods}

Seeds of three wheat (Triticum aestivum L.) genotypes, namely Barkat, Kanchan and Pavon 76 were collected from the Regional Wheat Research Center, Rajshahi and plants were grown in the field of Institute of Biological Sciences, University of Rajshahi, during November - January, 2000. Spikes were harvested when the flag leaf had just emerged and the microspores at the early to mid uninucleate stages were observed by 1:3 aceto-carmine staining. Harvested spikes were cold pretreated at $4-7^{\circ} \mathrm{C}$ in dark for $3-15$ days prior to culture. The selected spikes were deeped in $70 \%$ alcohol for a few seconds and transferred to $0.1 \%$ mercuric chloride solution for 5 - $7 \mathrm{~min}$. Finally the treated spikes were rinsed four - five times in sterile distilled water. Anthers were carefully removed from spikelets. Around 50 anthers were taken in dry and sterile Petri dishes $(60 \times 15 \mathrm{~mm})$ in the laminar airflow cabinet. Drought stress of different durations such as $1 \mathrm{hr}\left(\mathrm{T}_{1}\right), 3$ $\mathrm{hr}\left(\mathrm{T}_{2}\right), 5 \mathrm{hr}\left(\mathrm{T}_{3}\right), 7 \mathrm{hr}\left(\mathrm{T}_{4}\right)$ and $9 \mathrm{hr}\left(\mathrm{T}_{5}\right)$ were applied to precise anthers before they were cultured and their efficiency of androgenic response was compared with the control. Anthers were inoculated in AMS (Modified induction medium) comprised of AM (Anther medium), (Schmid 1990) with maltose (30 g/l) instead of sucrose, potato extract (100 ml/1), 2, 4-D (2 mg/l), Kn (0.5 mg/), IAA (1.0 mg/l), L-proline $(250 \mathrm{mg} / \mathrm{l})$, L-glutamine $(250 \mathrm{mg} / \mathrm{l})$, asparagine $(100 \mathrm{mg} / \mathrm{l})$ and glycin $(2$ $\mathrm{mg} / \mathrm{l})$. The $\mathrm{pH}$ of all media was adjusted to $5.8-6.0$.

Plated anthers were incubated at $28^{\circ} \mathrm{C}$ chamber in dark for four - six weeks for embryo induction. After the development of embryo like structures (ELS) which were transferred to semi-solidified regeneration medium (PM), (Schmid 1990) and placed them in a growth chamber of 16/8h light/dark regimes for shoot and root proliferation. Data were recorded on the main parameters of embryogenesis, regeneration on the following traits: ELS, expressed as the number of embryos per 100 anthers; total plants regeneration (TRP), expressed as the number of green and albino plantlets per 100 embryos; green plant regeneration (GPR), expressed as the number of green plantlets per 100 embryos; albino regenerated plants (ARP), expressed as the number of albino plants per 
100 embryos. For statistical analysis, data were transformed by the $\operatorname{ArcSin} \sqrt{ } \mathrm{P}$ methods for converting their multiplicative inter-effects of the traits into additive ones and subjected to ANOVA. LSD tests were used to compare androgenenic responses of different drought stress durations on anther culture of wheat varieties.

\section{Results and Discussion}

It was observed that the effect of different drought stress duration (hrs) on three wheat varieties with a defined induction medium (AMS) and evaluated their response on anther culture and plant regeneration is shown in Table 1. For all Table 1. Effect of drought stress on anther culture for production of embryos and their regeneration in three wheat genotypes.

\begin{tabular}{|c|c|c|c|c|c|c|}
\hline $\begin{array}{l}\text { Treat- } \\
\text { ments }\end{array}$ & Genotype & $\begin{array}{l}\text { Anther } \\
\text { response } \\
(\%)\end{array}$ & $\begin{array}{c}\text { Embryo } \\
\text { induction } \\
(\%)\end{array}$ & $\begin{array}{c}\text { Embryo } \\
\text { regeneration } \\
(\%)\end{array}$ & $\begin{array}{l}\text { Green } \\
\text { plants } \\
(\%)\end{array}$ & $\begin{array}{c}\text { Albino } \\
\text { plants } \\
(\%)\end{array}$ \\
\hline \multirow{3}{*}{ Control } & Barkat & 5.85 & 18.14 & 5.14 & 4.14 & 2.90 \\
\hline & Kanchan & 4.00 & 13.71 & 3.42 & 2.42 & 1.71 \\
\hline & Pavon 76 & 4.71 & 15.71 & 4.42 & 3.60 & 2.60 \\
\hline \multirow{5}{*}{$\mathrm{T}_{1}$} & Mean & 4.85 & 15.85 & 4.33 & 3.39 & 2.40 \\
\hline & Barkat & 15.60 & 50.00 & 20.14 & 15.42 & 8.14 \\
\hline & Kanchan & 11.85 & 42.57 & 17.00 & 13.00 & 6.90 \\
\hline & Pavon 76 & 12.71 & 44.14 & 15.71 & 11.71 & 7.43 \\
\hline & Mean & 13.39 & 45.57 & 17.62 & 13.38 & 7.49 \\
\hline \multirow{3}{*}{$\mathrm{T}_{2}$} & Barkat & 26.71 & 81.29 & 35.00 & 21.00 & 15.57 \\
\hline & Kanchan & 19.28 & 69.58 & 28.69 & 18.00 & 12.42 \\
\hline & Pavon 76 & 25.85 & 71.29 & 30.90 & 19.57 & 14.30 \\
\hline \multirow{5}{*}{$\mathrm{T}_{3}$} & Mean & 23.95 & 74.05 & 31.53 & 19.52 & 14.10 \\
\hline & Barkat & 10.57 & 33.28 & 13.30 & 8.00 & 7.14 \\
\hline & Kanchan & 8.42 & 27.42 & 14.42 & 6.30 & 8.90 \\
\hline & Pavon 76 & 9.14 & 28.57 & 15.30 & 8.42 & 9.42 \\
\hline & Mean & 9.38 & 29.76 & 13.34 & 7.57 & 8.49 \\
\hline \multirow{3}{*}{$\mathrm{T}_{4}$} & Barkat & 5.57 & 18.71 & 9.71 & 3.42 & 6.60 \\
\hline & Kanchan & 3.85 & 20.42 & 8.42 & 4.30 & 7.14 \\
\hline & Pavon 76 & 6.14 & 21.14 & 12.00 & 5.00 & 9.60 \\
\hline \multirow{5}{*}{$\mathrm{T}_{5}$} & Mean & 5.19 & 20.09 & 10.04 & 4.24 & 7.78 \\
\hline & Barkat & 2.57 & 12.57 & 6.00 & 1.60 & 5.30 \\
\hline & Kanchan & 2.28 & 8.14 & 5.14 & 1.14 & 4.42 \\
\hline & Pavon 76 & 3.00 & 8.85 & 4.71 & 0.90 & 3.71 \\
\hline & Mean & 2.62 & 9.85 & 5.28 & 1.21 & 4.48 \\
\hline
\end{tabular}

Control: Anthers directly cultured without any drought stress. $\mathrm{T}_{1}=1 \mathrm{hr}, \mathrm{T}_{2}=3 \mathrm{hr}, \mathrm{T}_{3}=5 \mathrm{hr}, \mathrm{T}_{4}=7 \mathrm{hr}$ and $T_{5}=9 \mathrm{hr}$ drought treated anthers. The anthers were kept in dry and sterile Petri dishes prior to culture. 
treatments, three varieties showed varied number of embryos and green plantlets. Drought stress for $3 \mathrm{hr}\left(\mathrm{T}_{2}\right)$ showed highest percentage of embryo production 81.29, 21.00 and 69.58 and green plantlets 18.00, 71.29 and 19.57, respectively in Barkat, Kanchan and Pavon 76 (Table 1). Among three varieties Barkat showed better response on embryo induction and green plantlets than Kanchan and Pavon 76 (Fig. A - E). Keller and Armstrong (1979) observed in Brassica, embryo yield increased by subjecting excised inflorescence to shortterm high temperature shock (i.e., $45^{\circ} \mathrm{C}$ for one $\mathrm{hr}$ followed by $40^{\circ} \mathrm{C}$ for three $\mathrm{hr}$ ) prior to anthers planting. Similarly, Ockendon and Sutherland (1987) found that
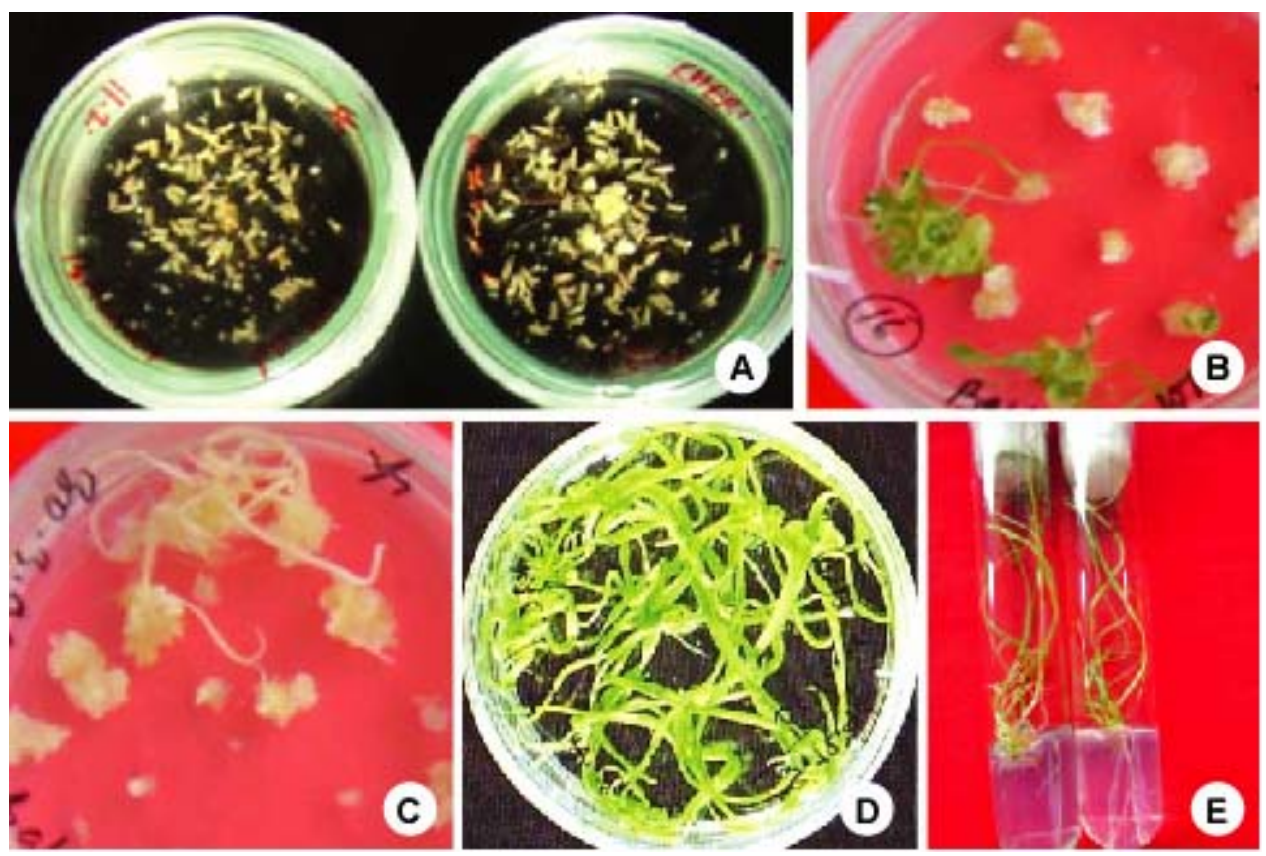

Fig. 1 A. Embryogenic structures in liquid induction medium from anther culture. B. Green plantlets regenerated from anther-derived embryoids in semi-solid medium. C. Regenerated albino plants. D. Regenerated green plantlets. E. Shoot and root formation from antherderived callus cultured on the plant medium.

in Brussels sprouts (B. oleracea var. gemmifera) yields up to 357 embryos per 100 anthers using a thermal shock treatment of $16 \mathrm{hr}$ at $35^{\circ} \mathrm{C}$ at the start of the culture period. Bueno et al. (1996) also obtained haploid embryos and regenerated plantlets in Quercus sp. by combining a starvation treatment in anther culture with a mid heat shock at $33^{\circ} \mathrm{C}$ for five days. Drought stress might be considered as parallel treatment of thermal shock. Least significant difference (LSD) values were calculated for undertaking the parameters and the results are presented in Table 2. All the evaluating traits of $\mathrm{T}_{1}, \mathrm{~T}_{2}$ and $\mathrm{T}_{3}$ were found significantly different from control. However, most of the traits in $\mathrm{T}_{4}$ and $\mathrm{T}_{5}$ did not significantly differ from control. 
All the varieties showed albino production with green plants, but $\mathrm{T}_{4}$ and $\mathrm{T}_{5}$ produced more albinos than green plants. Albino plant production was much higher (three - fourfold) than green plants in $T_{5}$ of Pavon 76 (Table 1). Sometimes pretreatment or culture conditions may affect albinisms by favoring the development of pollen containing normal or deleted forms of plastid DNA (Ouyang et al. 1987). The major problem in cereal anther culture is the formation of large numbers of albino plants (up to 90\%). The development of albinos may also be due to mutations or expression of recessive genes (Clapham 1977). Chen (1986) reported that the production of albino plants was influenced by many factors such as genotypes, medium composition, incubating conditions, and physiological status of donor plants. Hofinger et al. (2000) studied the phenomenon on molecular level and detected that chloroplast DNA changes induced albino plants, which indicating the involvement of genetic factors in the chloroplast genome. They have mapped chloropalst DNA rearrangements and

Table 2. Comparison between treatments and control using LSD test for anther response and its productivity on drought stress.

\begin{tabular}{|c|c|c|c|c|c|c|c|c|c|c|}
\hline \multirow[t]{2}{*}{$\begin{array}{l}\text { Treat- } \\
\text { ments }\end{array}$} & \multicolumn{2}{|c|}{$\begin{array}{l}\text { Anther } \\
\text { response }\end{array}$} & \multicolumn{2}{|c|}{$\begin{array}{l}\text { Embryo } \\
\text { induction }\end{array}$} & \multicolumn{2}{|c|}{$\begin{array}{c}\text { Embryo } \\
\text { regeneration }\end{array}$} & \multicolumn{2}{|c|}{$\begin{array}{l}\text { Green } \\
\text { plants }\end{array}$} & \multicolumn{2}{|c|}{$\begin{array}{l}\text { Albino } \\
\text { plants }\end{array}$} \\
\hline & Mean & Diff. & Mean & Diff. & Mean & Diff. & Mean & Diff. & Mean & Diff. \\
\hline $\mathrm{T}_{1}$ & 13.39 & $8.54^{* *}$ & 45.57 & $29.72^{* *}$ & 17.62 & $13.29^{* *}$ & 13.38 & $9.99^{* *}$ & 7.49 & $5.09^{* *}$ \\
\hline $\mathrm{T}_{2}$ & 23.95 & $19.10^{* *}$ & 74.05 & $58.20^{* *}$ & 31.53 & $27.20^{* * *}$ & 19.52 & $16.13^{* *}$ & 14.10 & $11.70^{* *}$ \\
\hline $\mathrm{T}_{3}$ & 9.38 & $4.53^{* *}$ & 29.76 & $13.91^{* *}$ & 13.34 & $9.01^{* *}$ & 7.57 & $4.18^{* *}$ & 8.49 & $6.09^{* *}$ \\
\hline $\mathrm{T}_{4}$ & 5.18 & $0.35^{\mathrm{NS}}$ & 20.09 & $4.24^{\mathrm{NS}}$ & 10.04 & $5.71^{* *}$ & 4.24 & $0.85^{\mathrm{NS}}$ & 7.78 & $5.38^{* *}$ \\
\hline $\mathrm{T}_{5}$ & 2.62 & $2.23^{\mathrm{NS}}$ & 9.85 & $6.00^{\mathrm{NS}}$ & 5.28 & $0.95^{\mathrm{NS}}$ & 1.21 & $2.18^{\mathrm{NS}}$ & 4.48 & $2.08^{\mathrm{NS}}$ \\
\hline Control & 4.85 & - & 15.85 & - & 4.33 & - & 3.39 & - & 2.40 & - \\
\hline LSD 5\% & \multicolumn{2}{|c|}{1.78} & \multicolumn{2}{|c|}{4.44} & \multicolumn{2}{|c|}{2.357} & \multicolumn{2}{|c|}{2.072} & \multicolumn{2}{|c|}{2.230} \\
\hline $1 \%$ & \multicolumn{2}{|c|}{2.535} & \multicolumn{2}{|c|}{6.315} & \multicolumn{2}{|c|}{3.352} & \multicolumn{2}{|c|}{2.947} & \multicolumn{2}{|c|}{3.172} \\
\hline
\end{tabular}

deletions in albino plants of wheat by using Southern hybridization and PCR techniques. However, the results obtained in the present study demonstrated that drought stress can be enhanced androgenesis and could be used as one of the potential factors having influence on embryo yield and regeneration of anther culture in wheat. On the other hand, drought stress treatment may have some influence on minimizing the unwanted albino plant production.

\section{Acknowledgements}

The author wishes to thank Dr. J. E. Schmid, ETH-Zürich, Switzerland for his valuable suggestions and useful comments about this work. Thanks are due also to Professor M. A. Bari Miah, Institute of Biological Sciences, University of Rajshahi, Bangladesh for his help in preparing the manuscript. 


\section{References}

Bajaj YPS (1990) Biotechnology in Agriculture and Forestry, Wheat: Section III: In Vitro Production of Haploids and Release of Varieties, Springer-Verlag, Berlin, 13: 285-478.

Bajaj YPS and Reinert J (1975) Growth and morphogenesis in isolated pollen and their protoplast. In: XII Botanical Congress, Leningrad, p. 278.

Bueno MA, Gomez A, Boscaiu M, Manzanera JA and Vicente O (1996) Haploid plants via embryogenesis on anther culture of Quercus suber L. COST 824, Gametic embryogenesis, Report of activities, 1995-1997, European Commission, pp. 95-96.

Cao MQ, Li Y, Lin F, Jiang T and Lin GS (1995) Application of anther culture and isolated microspore culture to vegetable crop improvement. Acta Hort. 392: 27-38.

Chen Y (1986) Anther and pollen culture of rice. In : Hu H and Yang H (Eds.) Haploid of higher plants in vitro. Springer, Berlin Heidelberg, pp. 44-66.

Chu CC, Wang CC, Sun CS, Chien NP, Yin KC and Hsu C (1973) Investigation on the induction and morphogenesis of wheat (Triticum vulgare) pollen plants. Acta Bot. Sin. 15: 1-11.

Cistué L, Soriano M, Castillo AM, Valles MP, Sanz JM and Echavarri B (2006) Production of doubled haploids in durum wheat (Triticum turgidum L.) through isolated microspore culture. Plant Cell Rep. 25(4): 257-64.

Clapham D (1977) Haploid induction in cereals. In : Applied and Fundamental Aspects of Plant Cell Tissue and Organ Culture, Reinert J and Bajaj YPS (Eds.), Springer-Verlag, Berlin, pp. 279-298.

Debergh P and Nitsch C (1973) Premiers resultans sur la culture in vitro de grains de pollen isoles chez la tomato. C. R. Acad. Sci. Ser. 276: 1281-1284.

Hofinger BJ, Ankele E, Gülly C, and Heberle-Bors E and Pfosser MF (2000) The involvement of the plastid genome in albino plant regeneration from microspores in wheat. Biotechnological Approaches for Utilisation of Gametic Cells, COST Action 824 final meeting, Bled, Slovenia 1-5 July, p. 215 - 228.

Keller WA and Armstrong KC (1979) Stimulation of embryogenesis and haploid production in Brassica campestris anther cultures by elevated temperature treatments. Theor Appl Genet. 55: 65-67.

Nitsch C and Norreel B (1973) Effect d'un choc thermique sur pouvoir embryogene du pollen de Datura innoxia cultive dans l'anthere on isole de l'anthere C. R. Acad. Sci. Ser. 276: 303-306.

Ockendon DJ and Sutherland RA (1987) Genetic and non-genetic factors affecting anther culture of Brussels sprouts (Brassica oleracea var. gemmifera). Theor Appl Genet. 74: 566-570.

Ouyang J, Hu H, Chuang CC and Tseng CC (1973) Induction of pollen plants from anthers of Triticum aestivum L. Cultured in vitro. Sci. Sin. 16: 79-95.

Ouyang JW, He DG, Feng GH and Jia SE (1987) The response of anther culture to culture temperature varies with growth conditions of anther donor plants. Plant Sci. 49: 145148.

Picard E and De Buyser J (1973) Obtention de plantules haplö̈des de Triticum aestivum L. à partir de cultures d'anthères in vitro. CR Acad. Sci. Ser. 277: 1463-1466. 
Schmid JE (1990) In vitro production of haploids in Triticum spelta. Biotechnology in Agriculture and Forestry, Bajaj YPS (Ed.), Springer-Verlag, Berlin, pp. 363-381.

Shen LY and Veilleux RE (1995) Effect of temperature shock and elevated incubation temperature on androgenic embryo yield of diploid potato. Plant Cell Tissue Org. Cult. 43 : 29-35.

Touraev A, Pfosser M, Vicente O and Heberle-Bors E (1996a) Stress as the major signal controlling the developmental fate of tobacco microspores: towards a unified model of induction of microspore/pollen embryogenesis. Planta 200: 144-152.

Touraev A, Indrianto A, Wratschko I, Vicente O and Heberle-Bors E (1996b) Efficient microspore embryogenesis in wheat (Triticum aestivum L.) induced by starvation at high temperature. Sex Plant Repr. 9(4): 209-215.

Zaki M and Dickinson H (1995) Modification of cell development in vitro: the effect of colchicine on anther and isolated microspore culture in Brassica napus. Plant Cell, Tissue and Org. Cult. 40: 255-270. 